\title{
Genes controlling ovulation rate in sheep
}

\author{
Grant W. Montgomery ${ }^{1}$, Susan M. Galloway², George H. Davis ${ }^{3}$ \\ and Kenneth P. McNatty ${ }^{4}$ \\ ${ }^{1}$ Genetic Epidemiology Laboratory, Queensland Institute of Medical Research and Joint \\ Genetics Program, The University of Queensland, Brisbane, Queensland, Australia; \\ ${ }^{2}$ AgResearch Molecular Biology Unit, Department of Biochemistry, University of Otago, \\ Dunedin, New Zealand; ' 3 Invermay Agricultural Centre, Mosgiel, New Zealand; and \\ ${ }^{4}$ AgResearch, Wallaceville Animal Research Centre, Upper Hutt, New Zealand
}

\begin{abstract}
Sheep provide a valuable model for studying the genetic control of ovulation rate. Recent progress includes the identification of mutations in BMP15 (bone morphogenetic protein 15) that increase ovulation rate in heterozygous carriers and block follicular development in homozygous carriers. The genes characterized to date appear to act principally within the ovary and result in earlier maturity of granulosa cells and reduced follicular size. There may also be other sites of action, and increased FSH concentrations appear to be important in the expression of the $\mathrm{Fec} B$ phenotype. A new locus on the $\mathrm{X}$ chromosome in New Zealand Coopworth sheep increases ovulation rate by about 0.4 and is maternally imprinted. Results from studies in the Cambridge and Belclare breeds indicate that further genes remain to be characterized. Finding the first mutations leading directly to variation in ovulation rate is likely to speed up the identification and molecular analysis of these other genes. There is still much to learn about follicular development and the control of litter size from genetic models in sheep.
\end{abstract}

Multiple ovulation in mammals is a complex trait influenced by genetic and environmental factors. Primates and many ruminants typically release a single oocyte at each cycle whereas species such as mice and pigs, capable of rearing many offspring, have consistently high ovulation rates. Within species, the number of follicles that mature is tightly regulated to ensure optimal fertility and maximum survival of offspring. Current models of follicular selection indicate that multiple ovulation is controlled both by concentrations of FSH near the time of follicular selection and by intraovarian factors (Campbell et al., 1995; Baird and Campbell, 1998; McNatty et al., 1999).

One approach to understanding critical pathways in complex regulatory systems is to find natural and induced mutations that influence the target phenotype. Sheep have proved a valuable model for the study of follicular growth and selection. Most breeds have one or two ovulations but there is wide variation in ovulation rate among different strains influenced by genetic background and the effects of age, season and nutrition. An important step forward was made by Piper and Bindon (1982) when they presented the first evidence for segregation of a locus with a major effect on litter size in the Booroola strain of Merino sheep, subsequently shown in New Zealand Booroola flocks to result from its additive effect on ovulation rate (Davis et al., 1982).

Email: grantM@qimr.edu.au
These observations generated a critical search for genes influencing ovulation rate in other strains of sheep and in other species. The best-characterized locus ( $F e C X$ ) was found in the New Zealand Romney breed (Inverdale, $F e c X^{\prime}$ ) and maps to the sheep X chromosome (Davis et al., 1991, 1992). Recent progress marks another milestone in our understanding of mechanisms controlling ovulation rate. The gene for the FecX locus has been identified and the first mutations that increase ovulation rate as part of the phenotype have been described (Galloway et al., 2000). Here, we review genetic studies in sheep and new contributions to our understanding of the mechanisms controlling ovulation rate.

\section{Follicle development}

Folliculogenesis begins when follicles leave the resting pool of primordial follicles and enter the growth phase. Growing follicles undergo a complex process of development that includes proliferation and differentiation of several cell types in the follicle. At the same time, the oocyte is undergoing developmental changes necessary for resumption of meiosis after the preovulatory surge of gonadotrophins. In sheep, the stages of follicular development have been classified from the number of granulosa cells in the largest cross-section of follicles (McNatty et al., 1999) to be types 1 (primordial), 1a (transitory), 2 (primary), 3 and 4 (preantral) and 5 (early antral; see Fig. 1). Type 1 refers to follicles with one layer of 


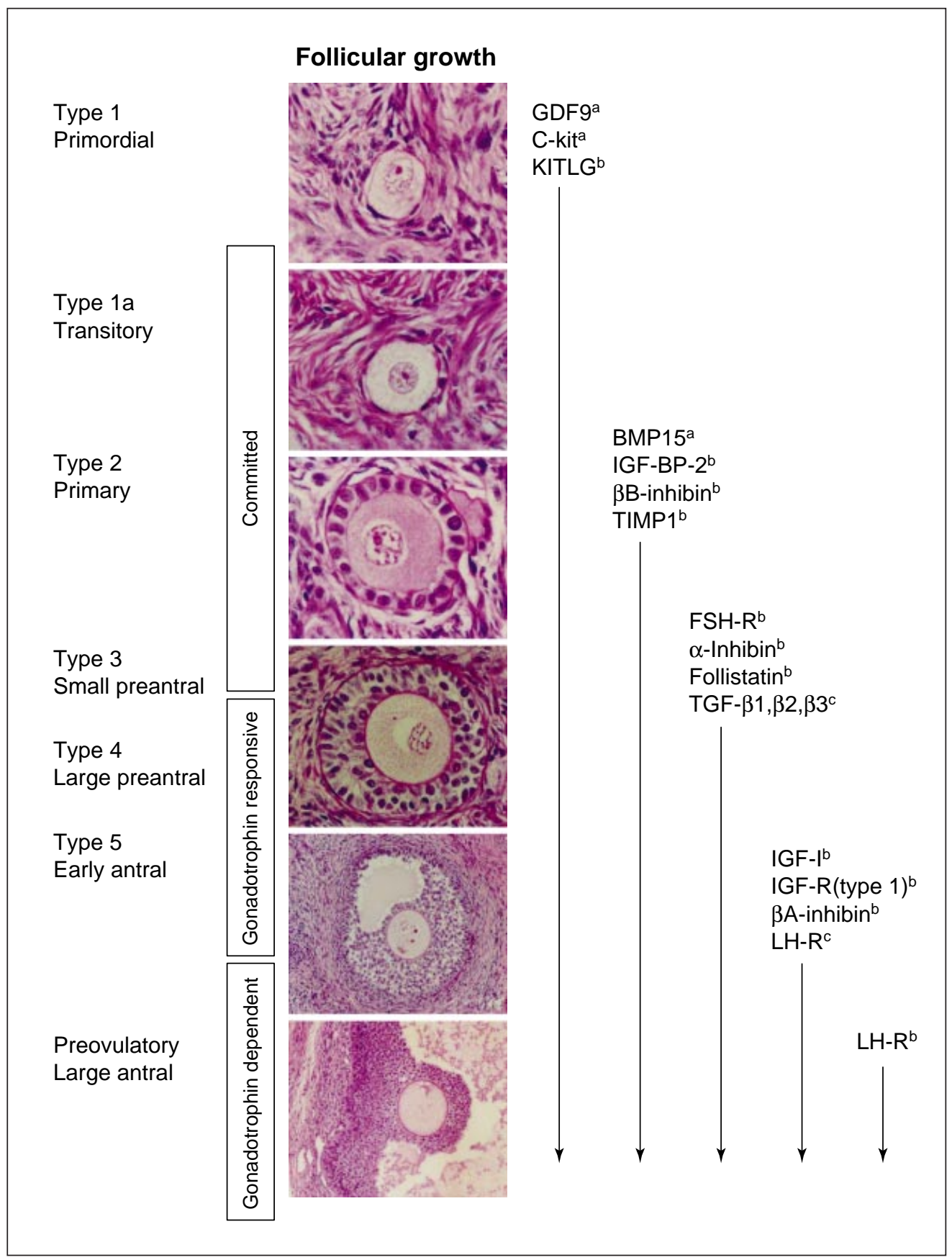

Fig. 1. Summary of the various stages of follicular growth in ewes together with the onset of expression of certain genes in (a) oocytes, (b) granulosa cells and (c) theca interna-externa (McNatty et al., 1999; Galloway et al., 2000; K. P. McNatty, unpublished). The solid vertical arrows indicate observations that all genes once expressed continue to be expressed at least until the time of the preovulatory LH surge. The Inverdale and Hanna gene mutations occur in the oocyte-derived BMP15 gene and thus block normal follicular growth from the type 2 stage of growth. The Booroola gene mutation, although unknown, affects follicular growth after the type 2 stage of growth but before the type 5 stage of development. Different classification systems have described the various stages of follicular growth as types 1-5, primordial to antral or as committed follicles to gonadotrophin-dependent follicles (McNatty, 1999; Scaramuzzi et al., 1999). BMP15: bone morphogenetic protein 15; GDF9: growth differentiation factor 9; IGF: insulin-like growth factor; IGF-BP: IGF-binding protein; KITLG: KIT ligand; TGF: transforming growth factor; TIMP1: tissue inhibitor of metalloproteinase 1. 
flattened granulosa cells; type 1a to follicles with one layer of cells that are a mixture of flattened and cuboidal granulosa cells; type 2 to one or two layers of cuboidal granulosa cells; type 3 to two to four layers of granulosa cells; type 4 to four to six layers of granulosa cells; and type 5 to more than five layers of granulosa cells with evidence of an antrum.

The classic endocrine control of ovarian function by FSH and LH forms one part of a complex regulatory network and interacts with systems of cell-cell interaction between different cell types in the follicle (Baird and Campbell, 1998; McNatty et al., 1999). A range of molecules exerts both paracrine and autocrine actions at every stage of folliculogenesis (McNatty et al., 1999). Genes expressed at different stages of follicular development in sheep are summarized (Fig. 1). Key questions in follicular development are: which signals control the exit of follicles from the resting pool; how are ovulatory follicles selected; and how is follicular dominance maintained? Genetic studies can address these questions where natural and induced mutations target key steps in these processes.

\section{Loci affecting ovulation rate}

In addition to genes in the Booroola $(F e c B)$ and Inverdale $(F e c X)$ sheep, there is evidence that major genes may be segregating in Icelandic (Johnmudsson and Adalsteinsson, 1985), Javanese (Bradford et al., 1986), Olkuska (Radomska et al., 1988), Cambridge (Owen et al., 1990; Hanrahan, 1991), Belclare (Hanrahan, 1991), Lacaune (Bodin et al., 1998) and Woodlands (Davis et al., 2001) sheep breeds. Some genes in these breeds may represent alleles for a smaller subset of genes. In most cases, it is impossible to carry out suitable crossbreeding experiments because of restrictions on the movement of sheep between countries. Molecular characterization of the loci and gene mapping will provide ways to test whether mutations are present in the same genes or the loci map to the same chromosomes.

\section{FecB locus}

The Booroola Merino strain carries a single autosomal locus named Fecundity Booroola (FecB) (Davis et al., 1982; Piper and Bindon, 1982). The effect of mutation is additive for ovulation rate with an increase of 1.65 for each copy (Piper et al., 1985). The effect on litter size is semi-dominant because embryonic losses cause partial failure of multiple pregnancy (Piper et al., 1985).

Phenotype. The most striking physiological effects of the $F e c B$ locus are on ovulation rate and the size and number of ovulatory follicles in the ovary. Follicles mature and ovulate at significantly smaller diameters in homozygous $(B B)$ and heterozygous $(B+)$ carrier ewes compared with non-carrier or wild-type $(++)$ ewes (McNatty and Henderson, 1987; Montgomery et al., 1992; Baird and Campbell, 1998). The smaller ovulatory follicles of $B B$ ewes contain fewer granulosa cells than ovulatory follicles in ++ ewes (McNatty and Henderson, 1987; Montgomery et al., 1992). The increased number of ovulatory follicles offsets the reduced number of granulosa cells in individual follicles. Consequently, both the total number of granulosa cells from all ovulatory follicles and total oestradiol production from the ovaries of $B+/ B B$ ewes are similar to those of ++ ewes (Montgomery et al., 1992; Souza et al., 1997). Some differences in follicular characteristics persist after hypophysectomy, but data indicate the different functional characteristics of ovaries in the Booroola genotypes may not be entirely independent of pituitary hormones (Fig. 2) (Montgomery et al., 1992). Despite the important differences in follicular development, oocytes from mature follicles in $B B$ genotypes appear fully competent and produce viable offspring with no apparent differences in fertility or embryo viability among genotypes.

Effects of FecB in females during fetal and neonatal development. During fetal development, there are differences in carriers of the $F e c B$ locus in the heart and mesonephros at 28 days, and in body mass and crownrump length between day 30 and day 40 (Fig. 2) (McNatty et al., 1995a). For the remainder of fetal and neonatal life, differences among the genotypes were found only within the ovary (Fig. 2). For example, ovarian development was retarded in $B B$ fetuses that had smaller mesonephri, smaller ovaries, fewer oogonia present at days 35-40, and fewer oocytes at day 55. However, a delay in loss of germ cells between day 75 and day 90 resulted in larger ovaries and a greater number of oogonia at day 90 . Moreover, $B B$ fetuses had fewer type 1 follicles at day 75 and day 90 and fewer type 2 and larger follicles at day 135 as well as during early neonatal life (Braw-Tal and Gootwine, 1989). However, by sexual maturity at $\geqslant 9$ months of age, no genotype differences were noted in the number of types $1-4$ or antral follicles (Fig. 1).

Hypothalamic-pituitary function in Booroola sheep. No differences in hypothalamic function have been noted in Booroola sheep, indicating that the principal effects of the $\mathrm{FecB}$ gene are likely to be downstream of the hypothalamus and possibly at the pituitary gland and the ovary (Montgomery et al., 1992; McNatty et al., 1993). The cumulative evidence for direct or indirect effects of the Booroola gene on pituitary function is substantial. The only genespecific effect on pituitary hormones was observed for FSH (McNatty et al., 1994). Moreover, in different ages and physiological states, some (Montgomery et al., 1992; BrawTal et al., 1993; McNatty et al., 1993, 1994; Phillips et al., 1993; Isaacs et al., 1998) but not all studies (Driancourt et al., 1991; Wheaton et al., 1996; Souza et al., 1997) found significantly higher FSH concentrations in $B B$ compared with ++ animals. In most of these reports, gene-specific differences were not found for $\mathrm{LH}$. Overall, the evidence indicates that the $B B$ animals have a greater $\mathrm{FSH}$ output per cell relative to ++ animals (McNatty et al., 1991; Heath et al., 1996). For example, in studies with ovariectomized hypothalamic-pituitary disconnected (HPD) animals, the FSH concentration $10 \mathrm{~min}$ after an exogenous pulse of 


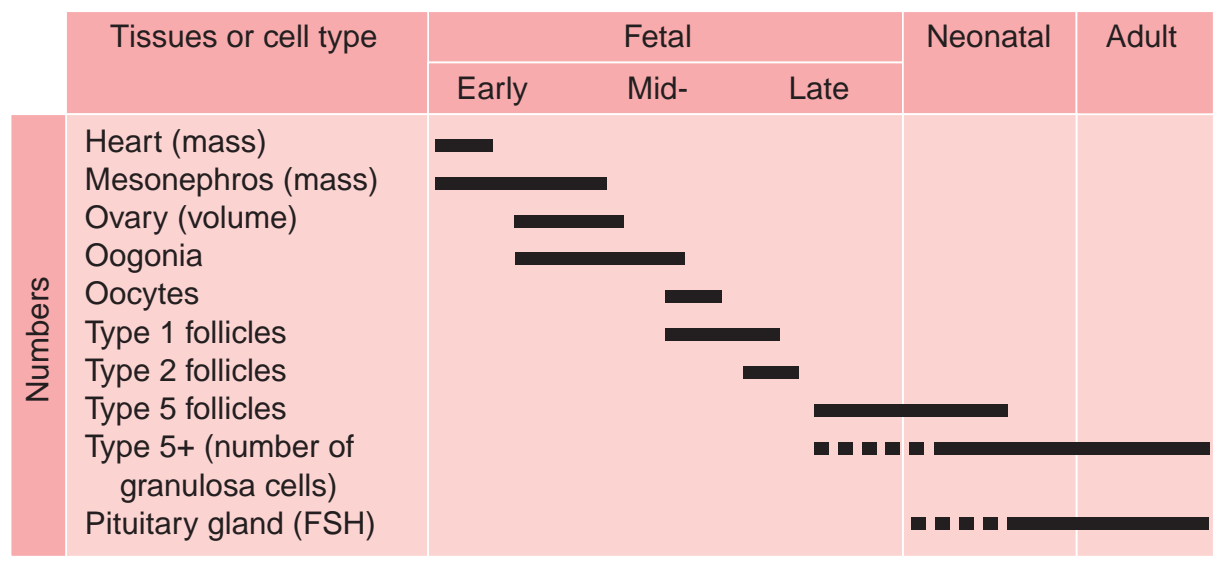

Fig. 2. Booroola genotype differences $(B B$ versus ++$)$ at different stages of fetal life and neonatal or adult life with respect to specific tissues or cell type. The solid bars define periods during which there are significant differences between Booroola genotypes in the development or physiology of different tissues or cell types. The dashed lines indicate that the ontogeny of the difference is not known.

GnRH (250 ng) was 1.6-fold higher in the BB than in the ++ genotype (McNatty et al., 1991).

Results from studies of HPD ovary-intact ewes and animals treated with GnRH agonist (Deslorelin) (Hudson et al., 1999) with comparable doses of gonadotrophins demonstrated that significantly more ++ than $B B$ animals ovulated. When $B B$ and ++ ewes were administered identical doses of $\mathrm{FSH}$, the mean ovulation rate and plasma concentrations of FSH in those animals that ovulated was the same in both genotypes. The higher mean ovulation rate in intact $B B$ compared with ++ ewes is probably due to effects of the $\mathrm{Fec} B$ gene at the ovary as well as on pituitary FSH release.

Genetic mapping. The search for markers linked to the $\mathrm{FecB}$ locus began during the late 1980s in several laboratories (Montgomery et al., 1992; Lanneluc et al., 1994). Despite a threefold difference in mean ovulation rate between homozygous $(B B)$ carriers and control $(++)$ ewes, problems remain in assigning phenotypes to individuals on the basis of lifetime records of ovulation rate. Phenotypes have been assigned directly on the basis of records of maximum ovulation rate (Davis et al., 1982; Montgomery et al., 1993), maximum likelihood techniques (Elsen et al., 1990) or treating the locus as a quantitative trait (Elsen et al., 1990). Errors in phenotype assignment may influence the estimated position of the locus, and incorrect phenotype assignment of key individuals can seriously mislead the search for the gene by positional cloning.

Linkage to the $F e c B$ locus was first detected with an anonymous microsatellite marker also linked to secreted phosphoprotein 1 (SPP1) (Montgomery et al., 1993). Additional genes from the same region were tested and the linkage group containing the $F e c B$ locus was mapped to sheep chromosome 6 (Montgomery et al., 1994). An approach using DNA fingerprinting was also successful in identifying markers linked to the $F e c B$ locus in Booroola flocks in France (Lanneluc et al., 1994), although the chromosome location for the gene could not be determined using these markers.

Subsequent studies have sought to identify the gene responsible by candidate positional cloning. The critical region for the $F e c B$ locus lies between the genes for SPP1 and alcohol dehydrogenase 2 (ADH2; Fig. 3) (Lord et al., 1998). Genes located on sheep chromosome 6 map to human chromosome 4 (Lanneluc et al., 1996; Lord et al., 1996). There is a large inversion in gene order between sheep chromosome 6 and human chromosome 4 near the region of the FecB locus (Lord et al., 1996). The breakpoint for one end of the inversion has been mapped to a small region of $150 \mathrm{~kb}$ pairs between the genes for SPP1 (secreted phosphoprotein 1) and DMP1 (dentin-specific acidic phosphoprotein) (Lumsden et al., 1999) outside the critical region for the $F e c B$ locus. Data on genes in the critical region from the human gene maps and the annotated human DNA sequence will provide information for positional cloning. Physical mapping and screening of candidate genes is in progress to try to locate the gene and mutation in carriers of the $F e c B$ locus.

Genes from chromosome 6 in sheep also map to pig chromosome 8 and a locus increasing ovulation rate maps to pig chromosome 8 (Rohrer, 1999; Wilkie et al., 1999). It is not clear whether this is the homologue of the FecB locus in pigs and it will be necessary to clone the genes or complete detailed comparative studies to decide whether the same gene is responsible for effects on ovulation rate in the two species.

\section{FecX locus}

The Inverdale $\left(F e c X^{I}\right)$ locus was identified in a prolific family of Romney sheep (Davis et al., 1995). A family line descended from a ewe (A281) with a history of 33 lambs 


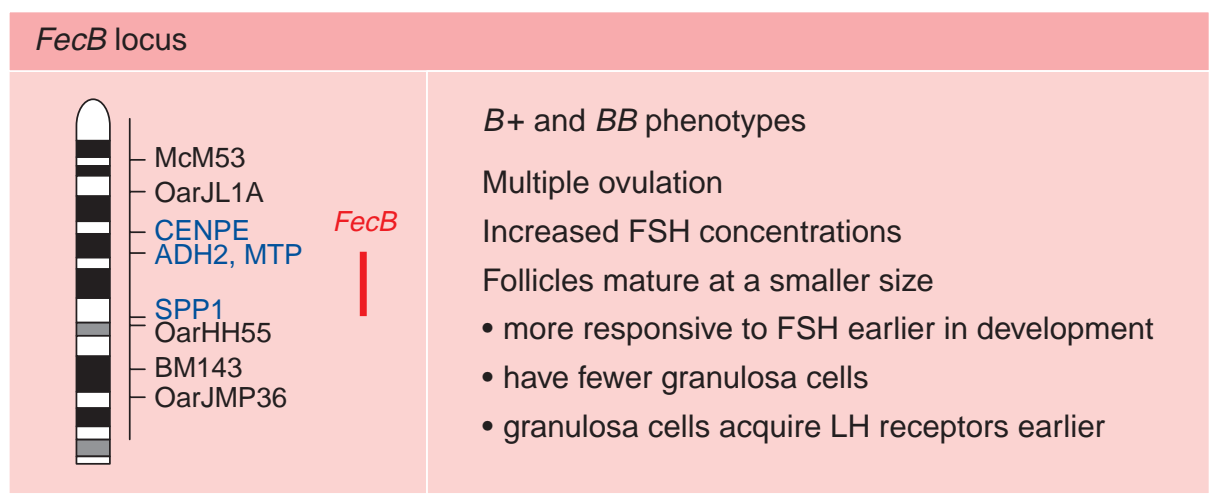

Fig. 3. A partial linkage map of sheep chromosome 6 (Lord et al., 1996; Lumsden et al., 1999) showing the location for the $F e c B$ locus together with the major phenotype for heterozygous $(B+)$ and homozygous $(B B)$ carriers of the mutation. Gene loci are shown in blue and microsatellite markers in black. The solid red bar shows the location of the FecB locus between the genes for alcohol dehydrogenase $2(A D H 2)$ and secreted phosphoprotein 1 (SPP1). Other genes shown on the map are those for centromere protein $\mathrm{E}$ (CENPE) and microsomal triglyceride transfer protein (MTP). Sheep and cattle microsatellite markers shown on the map are MCM53, OarJL1A, OarHH55, BM143, and OarJMP36.

from 11 lambings was identified in a flock screened for exceptional litter size (Davis et al., 1995). High ovulation rates were observed in female descendants of A281 within the flock (Davis et al., 1995). Segregation studies in the sons and grandsons of putative carriers demonstrated $X$ linkage (the locus was carried on the X chromosome; Davis et al., 1991, 1995). Subsequently, it was called the Inverdale fecundity locus $\left(F e c X^{\prime}\right)$. Mating rams with one copy of the gene $(I Y)$ with heterozygous $(I+)$ daughters demonstrated that homozygous (II) carriers have 'streak' ovaries and are infertile (Davis et al., 1992).

Fortunately for the subsequent gene search, a second strain of Romney sheep on the Hanna property $\left(F e C X^{H}\right)$, apparently unrelated to Inverdale sheep, was also found to carry the same X-linked phenotype (Davis et al., 1995). Complementation from crossing two strains is the classical method to determine whether two loci are the same. Crossing $\mathrm{Fec} \mathrm{X}^{I}$ with $\mathrm{Fec} \mathrm{X}^{H}$ animals produces $\mathrm{Fec} \mathrm{X}^{I} / \mathrm{Fec} \mathrm{X}^{\mathrm{H}}$ infertile females with streak ovaries indistinguishable from $F e c X^{\prime} / F e c X^{I}$ females (Davis et al., 1995) showing that the two strains carried mutations at the same locus.

Phenotype. The effect of the mutation in heterozygous carrier females is to increase ovulation rate by about 1.0 and litter size by about 0.6 (Davis et al., 1995). Homozygous females have small, flattened streak ovaries that show no sign of follicular activity (Davis et al., 1992). The streak ovaries contain primordial follicles, but follicles do not develop beyond the primary (type 2) stage.

Effects of $\mathrm{Fec}^{\mathrm{I}}$ in females during fetal development. No effects of $\mathrm{Fec} X^{I}$ genotype were detected in crown-rump length, weight of fetus, mass of the mesonephros or ovarian volume at 40 days of age (Smith et al., 1997). The number of germ cells present in the ovary of $I+$ carriers was significantly lower at 40 days and significantly higher at 90 days compared with non-carriers (Smith et al., 1997). At day 90 of gestation, mean diameters of the follicles in I+ ovaries were smaller than for those in ++ or II ovaries, due in part to differences in mean diameter of oocytes. However, from day 105 of gestation, follicular development in I+ carriers was similar to that in controls.

Germ cell populations in homozygous (II) carriers were similar to those in controls during early fetal development (Smith et al., 1997), but differences become apparent by day 105 of gestation. At this stage, the ovaries of $/ /$ fetuses are devoid of normal type 3 follicles and contain abnormal structures including oocytes devoid of follicular cells, follicles with degenerating oocytes or oocyte-free follicles (Braw-Tal et al., 1993; Smith et al., 1997). Comparisons of oocyte diameter and the number of granulosa cells show that as oocytes enlarge in I/ carriers, there is no parallel increase in the number granulosa cells or evidence of organized granulosa cell development. Results demonstrate that the normal transformation of a type 2 follicle into a type 3 follicle is blocked in homozygous carriers of the FecX mutation.

Effects of $\mathrm{Fec} \mathrm{X}^{\prime}$ on ovarian function in neonatal and adult female sheep. In neonatal and adult ewes, there were no differences between the three genotypes $(++, I+$ or $I I)$ in the total numbers of type 1, 1a or 2 follicles in the ovary (BrawTal et al., 1993; Smith et al., 1997). Thus the process of follicule formation and factors involved in the initiation of follicular growth are probably the same for all genotypes. However, the total number of antral follicles $(\geqslant 1 \mathrm{~mm}$ diameter) was found to be greater in adult $I+$ ewes than in ++ ewes (Shackell et al., 1993; McNatty et al., 1995b). This difference was due to the presence of more small antral 


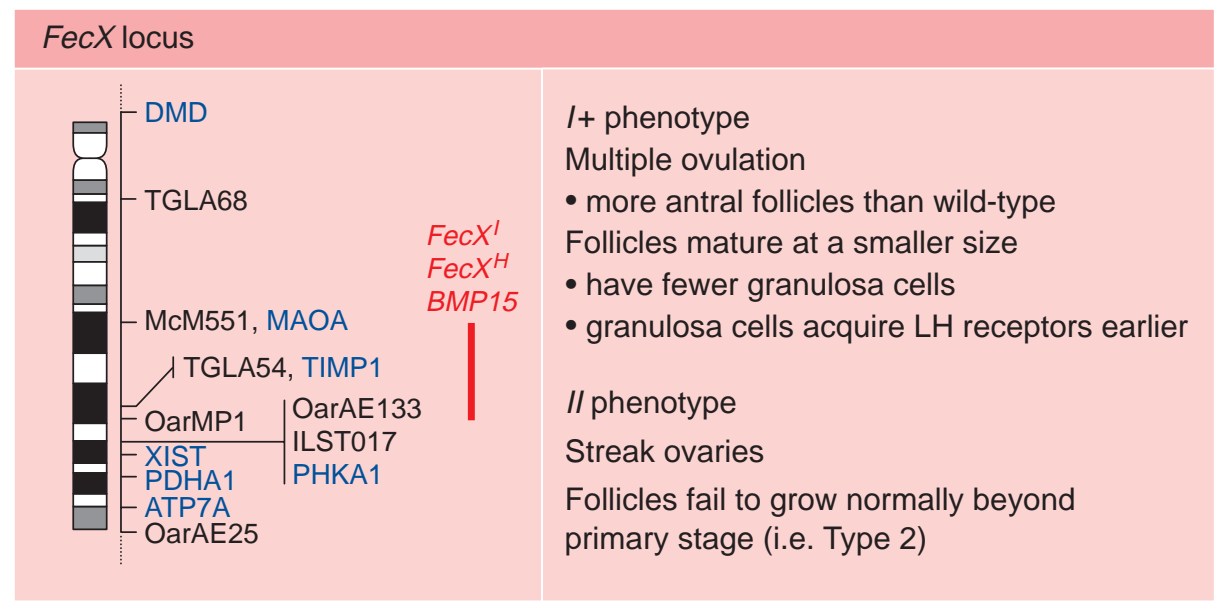

Fig. 4. A partial linkage map of the sheep X chromosome (Galloway et al., 2000) showing the location for the FecX locus together with the phenotypes for heterozygous $(I+)$ and homozygous (II) female carriers of the mutation. Gene loci are shown in blue and microsatellite markers in black. The solid red bar shows the location of the BMP15/FecX locus (Galloway et al., 2000) between the markers McM551 and OarMP1. Gene loci shown on the map are ATP7A (ATPase, Cu ${ }^{2+}$ transporting $\alpha$-polypeptide), DMD (Duchenne muscular dystrophy), BMP15 (bone morphogenetic protein 15, also known as growth differentiation factor 9B), MAOA (monoamine oxidase $\mathrm{A}$ ), PDHA1 (pyruvate dehydogenase E1 $\alpha$ ), PHKA1 (phosphorylase kinase $\alpha-1$ ), TIMP1 (tissue inhibitor of metalloproteinase 1) and XIST (inactive X-specific transcript). Sheep and cattle microsatellite markers are ILSTSOI7, MCM551, OarAE25, OarAE133, OarMP1, TGLA54 and TGLA68.

follicles and fewer granulosa cells in each of the small and large antral follicles of $1+$ compared with ++ ewes. Preovulatory follicles in $I+$ ewes also appear to mature at a smaller diameter and this earlier maturation may be attributable to greater sensitivity to FSH and an earlier acquisition of receptors for LH (Shackell et al., 1993).

Ovarian volumes in adult $/ /$ ewes are about $25 \%$ of those in non-carrier ewes, and the difference in ovarian volume occurs some time during the first 6 months after birth. This difference is probably due to the absence of normal follicular growth beyond type 2 follicles in the II ewes (Braw-Tal et al., 1993; Smith et al., 1997). Abnormal structures first observed in fetal ovaries are a common feature in the ovaries of neonatal and adult I/ ewes (BrawTal et al., 1993; McNatty et al., 1995b). These abnormal structures include oocyte-free follicles, a coalesced oocytefree structure and even larger abnormal tumour-like structures (Juengel et al., 2000).

Genetic mapping. The Fec $X$ locus was assigned to the sheep X chromosome by classical segregation analysis (Davis et al., 1991) and therefore mapping studies to locate the gene were concentrated on the $X$ chromosome. Carrier $(I Y)$ rams were mated to heterozygous $(I+)$ carrier ewes to generate pedigrees for marker studies (Galloway et al., 2000). Homozygous carrier ewes have streak ovaries and II daughters can be identified by direct observation of the ovaries before puberty (Davis et al., 1995) without the errors associated with phenotype assignment on the basis of ovulation rate in Booroola families.
A linkage map was constructed for the sheep $X$ chromosome (Galloway et al., 1996) and markers from the $X$ chromosome were screened in a three-generation flock in which the Inverdale gene was segregating. The Fec $X$ locus was mapped to a $10 \mathrm{cM}$ region at the centre of the $X$ chromosome (Fig. 4) (Galloway et al., 2000) in a region containing the genes for TIMP1 (tissue inhibitor of metalloproteinase 1) and MAOA (monoamine oxidase A). The equivalent region of the human $X$ chromosome is Xp11.2-p11.4 (Galloway et al., 2000).

BMP15 (bone morphogenetic protein 15), also known as GDF9B (growth differentiating factor 9B), is a member of the transforming growth factor superfamily, expressed specifically in the oocyte in several species (Dube et al., 1998; Laitinen et al., 1998). The gene mapped to the human $X$ chromosome Xp11.2 (Dube et al., 1998) and is a strong candidate for the Fec $X^{I}$ phenotype. The gene was shown to map to the sheep $X$ chromosome within the critical region and no recombinants were observed between the Fec $X$ locus and BMP15 in 78 coinformative meioses (Galloway et al., 2000). The ovine gene was sequenced and shown to be similar to the gene in humans, mice and rats, with a full length sequence of $1179 \mathrm{bp}$ containing two exons. Mutations were found in BMP15 in both $\mathrm{FecX}^{I}$ and $\mathrm{Fec} \mathrm{X}^{\mathrm{H}}$ carriers. In $\mathrm{Fec}^{H}$ carriers a single $\mathrm{C} \rightarrow \mathrm{T}$ transition at nucleotide 67 of the coding region for the mature peptide introduces a premature stop codon into the sequence, which probably results in complete loss of BMP15 function in the homozygous carriers of the $\mathrm{Fec}^{\mathrm{H}}$ variant.

In Fec $X^{I}$ carriers, a single $\mathrm{T} \rightarrow \mathrm{A}$ transversion at nucleotide 
position 92 results in the substitution of a valine with aspartic acid in a highly conserved region of the protein (Galloway et al., 2000). It appears likely that the amino acid change impairs the ability of BMP15 to form dimers and interferes with the biological action of BMP15 in ewes homozygous for the $F e c X^{I}$ variant.

\section{Fec $X 2$ locus}

The screened flock within which the FecX locus was identified has proved a valuable resource. Ewes were screened from the three major sheep breeds in New Zealand, Romney, Coopworth and Perendale. In 1984, high ovulation rates were recorded among daughters of one of the foundation Coopworth rams. This family was designated as the Woodlands line and an extensive progeny-testing programme was initiated in 1987 to determine whether a gene for ovulation rate segregated in this family.

Initial segregation studies indicated that high ovulation rates in this family did not follow simple Mendelian segregation (Davis et al., 2001). However, on the basis of experience with the $X$-linked inheritance of the Fec $X$ locus, careful progeny test records were kept over many years and different models of inheritance were tested. Records from 50 progeny-tested rams revealed that an imprinted gene on the X chromosome (Woodlands gene; FecX2) that increased ovulation rate by 0.39 was segregating in this Woodlands family (Davis et al., 2001). The Woodlands gene is maternally imprinted, as only females inheriting the gene from their sire display increased ovulation rates. Furthermore, the Woodlands gene is expressed only upon paternal inheritance from carrier males that are the progeny of dams in which the gene is silenced. Hence, the Woodlands gene is not expressed in ewes that receive it from either carrier dams (expressers or silenced) or from carrier males that were the progeny of expresser dams. The Woodlands gene is the first imprinted gene reported on the $X$ chromosome of sheep and is the only imprinted gene shown to increase ovulation rate. There is no evidence of the infertility that occurs in homozygous ewes carrying the Inverdale gene. Molecular and physiological studies have recently commenced to determine the location of FecX2 on the $X$ chromosome and the biochemical pathways involved.

\section{Cambridge and Belclare sheep}

Two other prolific sheep populations were developed as composite breeds using prolific sheep screened from a variety of genetic backgrounds (Hanrahan, 1991). The first was the Cambridge breed established in Britain in 1964. Litter size and ovulation rate in the Cambridge breed vary considerably, with ovulation rates ranging from 1 to 13 eggs shed and $2.5 \%$ of litters $\geqslant 6$ (Hanrahan, 1991). An analysis of ovulation rate records in Cambridge ewes at Bangor indicated the presence of a major gene with an effect size of 1.72 for ovulation rate in 2- and 3-year-old ewes (Owen et al., 1990). Results were consistent with a gene frequency of 0.3-0.4 and the absence of dominance.
An association has been reported between ovulation rate and HBB (haemoglobin) genotypes in Cambridge sheep (Glazko et al., 1997). HBB maps close to the FSHB locus on sheep chromosome 15, indicating $\mathrm{FSH}$ as a candidate gene. However, it is possible that the association with the HBB locus is due to inclusion of the Finn breed since this breed differs in the frequency of HBB alleles compared with other European breeds (Sise et al., 1991). Segregation studies are necessary to demonstrate linkage to the HBB locus in the Cambridge breed.

In Ireland, the Belclare breed was developed in the late 1970 s by reciprocal crossing of Fingalway and High Fertility prolific lines (Hanrahan, 1991). Ewes with exceptionally high ovulation rate have been recorded in the Belclare breed, and the repeatability of ovulation rate is high in the daughters of these ewes, indicating possible segregation of a major gene or genes (Hanrahan, 1991; Reynaud et al., 1999). Studies of ovaries in putative heterozygous carriers or non-carriers in the Belclare breed demonstrated differences in the number and size of ovulatory follicles (Reynaud et al., 1999). Carrier ewes had significantly more ovulatory follicles, but these were smaller and contained fewer granulosa cells. Segregation studies support the presence of major genes in the Belclare breed (Webb et al., 1998; Reynaud et al., 1999), but the situation is complicated since more than one gene may be present.

Ewes with infertility and non-functional ovaries have been observed in both the Cambridge and Belclare breeds (Hanrahan, 1991; Owen, 1996; Webb et al., 1998). In some prolific breeds, abnormalities of the reproductive tract can occur through $X X / X Y$ chimaerism (Hanrahan, 1991). No $X X / X Y$ chimaerism was detected in a small number of infertile female Cambridge sheep with hypoplastic ovaries and a small uterus (Hanrahan, 1991). Unlike the homozygous carriers of the $F e c X$ locus, some sterile ewes of the Belclare and Cambridge breeds do contain small growing follicles, and follicles are occasionally visible on the surface of the ovary (Hanrahan, 1991; Webb et al., 1998). Evidence from breeding studies indicates that a recessive gene that appears to follow autosomal rather than X-linked inheritance causes ovarian hypoplasia in the Belclare breed (Webb et al., 1998; Reynaud et al., 1999). Ewes known to be carriers of the gene for ovarian hypoplasia do not always have high ovulation rates themselves, and carrier rams can be classified as non-carriers of a gene for ovulation rate (Reynaud et al., 1999). However, ewes with exceptionally high ovulation rates have descendants with ovarian sterility, indicating some interaction between the loci involved in ovulation rate and ovarian hypoplasia, or that the genes are linked. Both breeds received genetic contributions from the Lleyn breed and, since infertile ewes have been reported in the Lleyn breed (Vaughan et al., 1997), a gene influencing ovarian hypoplasia may have come from this source.

The segregation patterns for putative major genes in the Belclare and Cambridge breeds are complex, but offer valuable models for further study of genes affecting ovulation rate. Further segregation data together with genetic 
analysis for the presence of mutations in BMP15 and linkage to markers close to the $\mathrm{Fec} X$ locus may help clarify the nature of the genes and the relationship (if any) to known loci influencing ovulation rate. In view of the recent segregation data for the FecX2 locus indicating imprinting of an X-linked gene and the reported segregation patterns in the Belclare breed, the possibility of an imprinted gene should be considered.

\section{Mechanisms controlling follicle selection and ovulation rate}

The search for genes in the pathway controlling ovulation rate in sheep has been very productive. Identifying individual genes has contributed significantly to our understanding and changed our view of inherited variation for this important phenotype. Chromosome locations are known for three genes. Two of these are on the $\mathrm{X}$ chromosome, with one gene subject to imprinting. The discovery of new loci, combined with complex patterns of inheritance and the difficulty of diagnosis based on ovulation rate records, indicates that genes of moderate-to-large effect may be common in different sheep populations.

The genes all act at different points along the pathway of follicular development and once follicles have left the primordial follicle pool. The Fec $X^{\prime} / B M P 15$ knockout acts early in the growth phase (type 2 follicles; Fig. 1). Failure of the BMP15 signal from the early developing oocyte in II ewes means that granulosa cells fail to divide and support the oocyte (Braw-Tal et al., 1993; McNatty et al., 1995b). Consequently, the oocyte enlarges, but then degenerates. The gene or genes causing infertility in the Cambridge and Belclare breeds appear to act later than the Fec $X^{1 / B M P 15}$ knockout mutation since small growing follicles are seen in the ovaries of these sheep (Hanrahan, 1991; Webb et al., 1998). Alternatively, the gene acts at a similar stage, but the mutation responsible is less severe than the BMP15 knockout so some follicles can progress further. Segregation data indicate that the gene is inherited as an autosomal recessive (Webb et al., 1998; Reynaud et al., 1999) and is therefore not BMP15. Given the similarity in the phenotype, the closely related growth factor GDF9 (McGrath et al., 1995) is a candidate gene for the infertility observed in Cambridge sheep.

Inactivation of one copy of BMP15 in heterozygous $(I+)$ carriers of the $F e c X^{I}$ results in increased ovulation rate from a larger pool of antral follicles with granulosa cells responsive to LH (Shackell et al., 1993). Reduced concentrations of active BMP15 may reduce the number of mitotic divisions in the granulosa cells and lead to a reduced amount of steroid and inhibin release by each follicle, thereby delaying the suppressive effects on plasma FSH and allowing selection of additional follicles. Another possibility is that reduced concentrations of BMP15 affect the actions of other growth factors from the oocyte on proliferation and differentiation of granulosa cells. Further work with the heterozygous BMP15 knockout should help to determine the interactions of BMP15 with other growth factors and how this mutation affects ovulation rate.

The FecB locus acts later in follicular development. Functional differences among genotypes are apparent in ovarian follicles near the time of antrum formation (type 4-5 follicles; Fig. 1). It is still not known why ovarian follicles in $B+$ and $B B$ ewes undergo one fewer doubling of their population of granulosa cells than those in ++ ewes (that is, 17 versus 18 doublings; Fig. 2). It may be that just before or near the time of antrum formation, more granulosa cells in follicles in $B B$ ewes are induced to enter a differentiation pathway rather than to undergo another round of mitosis. The data also support an effect of the $F e c B$ gene/mutation at the pituitary gland. The reason for variation in $\mathrm{FSH}$ differences among studies is not known, but could relate to genetic background. Mutations in the FSH receptor can result in higher concentrations of $\mathrm{FSH}$ and reduced response to exogenous FSH administration (Perez Mayorga et al., 2000), although FSHR is excluded as the site for the FecB mutation (Montgomery et al., 1995). It is likely that the $F e c B$ gene product is expressed in the ovary and the pituitary gland, or ovarian expression indirectly influences circulating FSH by some mechanism yet to be determined.

In the only study comparing the effects of $\mathrm{FecB}$ and $\mathrm{Fec} X$ alone and in combination, Davis et al. (1999) concluded that the effect of both genes on ovulation rate was multiplicative by demonstrating no suppressive effects of either locus. The effect of $F e c B$ in either the presence or absence of FecX was to increase ovulation rate by about $90 \%$ and the effect of $\mathrm{Fec} X$ in the presence or absence of $\mathrm{Fec} B$ was to increase ovulation rate by $44 \%$. These results contrast with previous studies of $F e c B$ (Piper et al., 1985) that indicated that the effect of $F e c B$ on ovulation rate in flocks at different levels of prolificacy was additive rather than multiplicative. The effect of the two genes in combination was $34 \%$ higher than expected from an additive model, indicating that there may be some complimentary gene action between the loci.

In carriers of the $F е c B$ locus, there are gene-specific differences in development that extend beyond the reproductive axis. There is evidence for a quantitative trait locus (QTL) with a significant effect on growth from birth to weaning $20 \mathrm{cM}$ distal to the $\mathrm{FecB}$ locus (Walling et al., 2000). Sheep inheriting the QTL allele on the same haplotype as the Booroola allele in the founding sires are, on average, $1.4 \mathrm{~kg}$ lighter at weaning. Therefore, genespecific differences observed in fetal size may result from effects of a QTL linked to the $\mathrm{FecB}$ locus. Consequently, direct effects of the mutation or mutations affecting ovulation rate may be restricted to the developing ovary, delaying development at several stages, similar to effects of the FecX locus.

Although the different genes may act first at different stages of follicular development, increased ovulation rate is associated with reduced size of mature follicles and fewer granulosa cells. Thus, it appears that a common mechanism may be operating. BMP15 has been identified as a key gene 
influencing ovulation rate. Characterization of the genes and mutations in other breeds and strains will show whether they form part of the transforming growth factor $\beta$ (TGF $\beta$ ) signalling pathway or are part of other intersecting pathways that provide the control of ovulation rate and distinct species variation in litter size. Understanding some of the key molecular events may also help us to understand the mechanisms for effects of age, nutrition and season on ovulation rate.

\section{Conclusions}

In summary, genes influencing ovulation rate in sheep act principally in the ovary, resulting in delays in ovarian development during fetal life and different patterns of follicular development in adults. There is evidence that there are multiple loci in different sheep populations and further segregation and genetic marker studies should be carried out to characterize the nature of genetic variation in the Cambridge, Belclare and other breeds. These studies will help to clarify the number of loci and the relationships (if any) to $F e c B$ and $F e c X$ loci. There are some similarities in the gene effects on follicular development leading to increased ovulation rate across the different genotypes, possibly acting through the same pathway as the BMP15 mutations in heterozygous Fec $X$ carriers. The discovery of the first mutations to alter ovulation rate directly provides a key to the pathways in the ovary that control follicular development and ovulation rate. Genes affecting ovulation rate in the other breeds may provide clues to additional players in the BMP15 pathway, or uncover alternative mechanisms. There remains much to learn about follicular development and the control of litter size from genetic models in sheep.

\section{Note added in proof}

Since writing this review, it has been shown that sheep carrying the FecB locus have a mutation (Q249R) in the intracellular kinase domain of bone morphogenetic protein 1B receptor (BMPR1B; Wilson et al., 2001). This is the second mutation in a gene from the TGF $\beta$ signalling pathway influencing ovulation rate in sheep. BMPR1B is expressed in the oocyte and granulosa cells in the ovary, and in other tissues including the pituitary gland.

\section{References}

Key references are identified by asterisks.

Baird DT and Campbell BK (1998) Follicle selection in sheep with breed differences in ovulation rate Molecular and Cellular Endocrinology 145 89-95

Bodin L, Elsen JM, Poivey JP, San Cristobal-Gaudy M, Belloc JP and Eychenne $\mathbf{F}$ (1998) Hyper-prolificacy in the French Lacaune sheep breed Proceedings of the World Congress of Genetics Applied to Livestock Production 27 11-14

Bradford GE, Quirk JF, Sitorius P, Inounou I, Tiesnamurti B, Bell FL, Fletcher IC and Torrell DT (1986) Reproduction in Javanese sheep: evidence for a gene with a large effect on ovulation rate and litter size Journal of Animal Science 63 418-431

Braw-Tal R and Gootwine E (1989) Pituitary response to GnRH and ovariectomy in Booroola-Awassi and Awassi ewe lambs Journal of Reproduction and Fertility 87 73-80
Braw-Tal R, McNatty KP, Smith P, Heath DA, Hudson NL, Phillips DJ, McLeod BJ and Davis GH (1993) The ovaries of ewes homozygous for the X-linked Inverdale gene ( $\left.F e c X^{\top}\right)$ are devoid of secondary and tertiary follicles but contain many abnormal structures Biology of Reproduction 49 895-907

Campbell BK, Scaramuzzi RJ and Webb R (1995) Control of antral follicle development and selection in sheep and cattle Journal of Reproduction and Fertility Supplement 49 335-350

Davis GH, Montgomery GW, Allison AJ, Kelly RW and Bray AR (1982) Segregation of a major gene influencing fecundity in progeny of Booroola sheep New Zealand Journal of Agricultural Research 25 525-529

Davis GH, McEwan JC, Fennessy PF, Dodds KG and Farquhar PA (1991) Evidence for the presence of a major gene influencing ovulation rate on the X chromosome of sheep Biology of Reproduction 44 620-624

Davis GH, McEwan JC, Fennessy PF, Dodds KG, McNatty KP and O WS (1992) Infertility due to bilateral ovarian hypoplasia in sheep homozygous (FecXI FecXI) for the Inverdale prolificacy gene located on the $X$ chromosome Biology of Reproduction 46 636-640

Davis GH, McEwan JC, Fennessy PF and Dodds KG (1995) Discovery of the Inverdale gene $(\mathrm{FeCX})$ Proceedings of the New Zealand Society of Animal Production 55 289-290

Davis GH, Dodds KG and Bruce GD (1999) Combined effect of the Inverdale and Booroola prolificacy genes on ovulation rate in sheep Proceedings of the Association for the Advancement of Animal Breeding and Genetics 13 74-77

*Davis GH, Dodds KG, Wheeler R and Jay NP (2001) Evidence that an imprinted gene on the $\mathrm{X}$ chromosome increases ovulation rate in sheep Biology of Reproduction 64 216-221

Driancourt MA, Bodin L and Fry RC (1991) FSH secretion, its regulation and its relationship with ovulation rate in a range of prolific and non-prolific breeds of sheep. In Major Genes for Reproduction in Sheep pp 125-134 Eds JM Elsen et al. INRA, Paris

Dube JL, Wang P, Elvin J, Lyons KM, Celeste AJ and Matzuk MM (1998) The bone morphogenetic protein 15 gene is $X$ linked and expressed in oocytes Molecular Endocrinology 12 1809-1817

Elsen JM, Le Roy P and Goffinet B (1990) Comparisons of four statistical tests for genotype determination at a major locus of progeny tested sires Journal of Animal Breeding and Genetics 108 167-173

Galloway SM, Harahan V, Dodds KG, Potts MD, Crawford AM and Hill DF (1996) A linkage map of the ovine X chromosome Genome Research 6 667-677

*Galloway SM, McNatty KP, Cambridge LM et al. (2000) Mutations in an oocyte-derived growth differentiation factor gene (BMP15) cause increased ovulation rate and infertility in a dosage-sensitive manner Nature Genetics 25 279-283

Glazko VIL, Owen JB, Ap Dewi I and Axford REF (1997) An association of haemoglobin protein (HBB) with ovulation rate in Cambridge sheep Animal Science 64 279-282

Hanrahan JP (1991) Evidence for single gene effects on ovulation rate in the Cambridge and Belclare breeds. In Major Genes for Reproduction in Sheep pp 93-102 Eds JM Elsen et al. INRA, Paris

Heath DA, Caldani M and McNatty KP (1996) Relationships between the number of immunostaining gonadotropes and the plasma concentrations of gonadotrophins in ewes with and without the $F e c B B$ gene Journal of Reproduction and Fertility 106 73-78

Hudson NL, O'Connell AR, Shaw L, Clarke IJ and McNatty KP (1999) Effect of exogenous $\mathrm{FSH}$ on ovulation rate in homozygous carriers or noncarriers of the Booroola $F e c B B$ gene after hypothalamic-pituitary disconnection or after treatment with a GnRH agonist Domestic Animal Endocrinology 16 69-80

Isaacs KL, McNatty KP, Condell L, Shaw L, Heath DA, Hudson NL, Littlejohn RP and McLeod BJ (1998) Plasma FSH, LH and immunoreactive inhibin concentrations in $\mathrm{FecBB} / \mathrm{FecB}$ and $\mathrm{FecB}+/$ $F e c B+$ Booroola ewes and rams from birth to 12 months of age Journal of Reproduction and Fertility 103 89-97

Johnmudsson JV and Adalsteinsson S (1985) Simple genes for fecundity in Icelandic sheep. In Genetics of Reproduction in Sheep pp 159-168 Eds RB Land and DW Robinson. Butterworths, London

Juengel JL, Quirke LD, Tisdall DJ, Smith P, Hudson NL and McNatty KP 
(2000) Gene expression in abnormal ovarian structures of ewes homozygous for the Inverdale prolificacy gene Biology of Reproduction 62 1467-1478

Laitinen M, Vuojolainen K, Jaatinen R, Ketola I, Aaltonen J, Lehtonen E, Heikinheimo $\mathbf{M}$ and Ritvos $\mathbf{O}$ (1998) A novel growth differentiation factor9 (GDF-9) related factor is co-expressed with GDF-9 in mouse oocytes during folliculogenesis Mechanisms of Development 78 135-140

Lanneluc I, Drinkwater RD, Elsen JM, Hetzel DJ, Nguyen TC, Piper LR, Thimonier J, Harrison B and Gellin J (1994) Genetic markers for the Booroola fecundity $(\mathrm{Fec}$ ) gene in sheep Mammalian Genome 5 26-33

Lanneluc I, Mulsant P, Saidi-Mehtar N and Elsen JM (1996) Synteny conservation between parts of human chromosome $4 q$ and bovine and ovine chromosomes 6 Cytogenetics and Cell Genetics 72 212-214

Lord EA, Lumsden JM, Dodds KG, Henry HM, Crawford AM, Ansari HA, Pearce PD, Maher DW, Stone RT, Kappes SM, Beattie CW and Montgomery GW (1996) The linkage map of sheep chromosome 6 compared with orthologous regions in other species Mammalian Genome 7 373-376

Lord EA, Davis GH, Dodds KG, Henry H, Lumsden JM and Montgomery GW (1998) Identification of Booroola carriers using microsatellite markers Wool Technology and Sheep Breeding 46 245-249

Lumsden JM, Lord EA, Hirst KL, Dixon MJ and Montgomery GW (1999) Mapping of DMP1 and IBSP in sheep defines an inversion breakpoint with respect to human chromosome $4 \mathrm{q}$ Genetics and Molecular Biology 22 29-31

McGrath SA, Esquela AF and Lee SJ (1995) Oocyte-specific expression of growth/differentiation factor-9 Molecular Endocrinology 9 131-136

McNatty KP and Henderson KM (1987) Gonadotrophins, fecundity genes and ovarian follicular function Journal of Steroid Biochemistry 27 365-373

McNatty KP, Hudson NL, Shaw L, Condell LA, Ball K, Seah S-L and Clarke IJ (1991) $\mathrm{GnRH}$-induced gonadotrophin secretion in ovariectomized Booroola ewes with hypothalamic-pituitary disconnection Journal of Reproduction and Fertility 91 583-592

McNatty KP, Hudson NL, Lun S, Heath DA, Shaw L, Condell L, Phillips DJ and Clarke IJ (1993) Gonadotrophin-releasing hormone and the control of ovulation rate by the FecB gene in Booroola ewes Journal of Reproduction and Fertility 98 97-105

McNatty KP, Hudson NL, Shaw L and Moore L (1994) Plasma concentrations of $\mathrm{FSH}, \mathrm{LH}$, thyroid-stimulating hormone and growth hormone after exogenous stimulation with $\mathrm{GnRH}, \mathrm{TRH}$ and $\mathrm{GHRH}$ in Booroola ewes that are homozygous carriers or non-carriers of the FecB gene Journal of Reproduction and Fertility 102 177-183

McNatty KP, Smith P, Hudson NL, Heath DA, Tisdall DJ, O W-S and BrawTal R (1995a) Development of the sheep ovary during fetal and early neonatal life and the effect of fecundity genes Journal of Reproduction and Fertility Supplement 49 123-135

McNatty KP, Smith P, Hudson NL, Lun S, Heath D, Shackell G and Korrigan $\mathbf{K}$ (1995b) Ovarian charateristics in Inverdale ewes heterozygous (I+) and homozygous (II) for the Inverdale gene Proceedings of the New Zealand Society of Animal Production 55 301-303

*McNatty KP, Heath DA, Lundy T, Fidler AE, Quirke L, O'Connell A, Smith P, Groome N and Tisdall DJ (1999) Control of early ovarian follicular development Journal of Reproduction and Fertility Supplement 54 3-16

Montgomery GW, McNatty KP and Davis GH (1992) Physiology and molecular genetics of mutations that increase ovulation rate in sheep Endocrine Reviews 13 309-328

*Montgomery GW, Crawford AM, Penty JM, Dodds KG, Ede AJ, Henry HM, Pierson CA, Lord EA, Galloway SM, Schmack AE, Sise JA, Swarbrick PA, Hanrahan V, Buchanan FC and Hill DF (1993) The ovine Booroola fecundity gene $(F e c B)$ is linked to markers from a region of human chromosome 4q Nature Genetics 4 410-414

Montgomery GW, Lord EA, Penty JM, Dodds KG, Broad TE, Cambridge LM, Sunden SLF, Stone RT and Crawford AM (1994) The Booroola fecundity (FecB) gene maps to sheep chromosome 6 Genomics 22 148-153

Montgomery GW, Tate ML, Henry HM, Penty JM and Rohan RM (1995) The follicle-stimulating hormone receptor and luteinizing hormone receptor genes are closely linked in sheep and deer Journal of Molecular Endocrinology 15 259-265
Owen JB (1996) The Cambridge breed. In Prolific Sheep pp 161-173 Ed MH Fahmy. CAB International, Wallingford

Owen JB, Whitaker CJ, Axford RFE and Ap Dewi I (1990) Expected consequences of the segregation of a major gene in a sheep population in relation to observations on the ovulation rate of a flock of Cambridge sheep Animal Production 51 277-282

Perez Mayorga M, Gromoll J, Behre HM, Gassner C, Nieschlag E and Simoni M (2000) Ovarian response to follicle-stimulating hormone (FSH) stimulation depends on the FSH receptor genotype Journal of Clinical Endocrinology and Metabolism 85 3365-3369

Phillips DJ, Hudson NL and McNatty KP (1993) Effects of ovariectomy and genotype on bioactive $\mathrm{FSH}$ in plasma and pituitary of Booroola ewes Journal of Reproduction and Fertility 98 559-565

Piper LR and Bindon BM (1982) The Booroola Merino and the performance of medium non-Peppin crosses at Armidale. In The Booroola Merino pp 9-20 Eds LR Piper, BM Bindon and RD Nethery. CSIRO, Melbourne

Piper LR, Bindon BM and Davis GH (1985) The single gene inheritance of the high litter size of the Booroola Merino. In Genetics of Reproduction in Sheep pp 115-125 Eds RB Land and DW Robinson. Butterworths, London

Radomska M, Martynuik E, Klewiec J and Knothe A (1988) Inheritance of high prolificacy of the Olkuska sheep (preliminary results) Journal of Agricultural Science Finland 60 597-598

* Reynaud K, Hanrahan JP, Donovan A and Driancourt MA (1999) Markers of follicle function in Belclare-cross ewes differing widely in ovulation rate Journal of Reproduction and Fertility 116 51-61

Rohrer GA (1999) Mapping four genes from human chromosome 4 to porcine chromosome 8 further develops the comparative map for an economically important chromosome of the swine genome Animal Genetics 30 60-62

Scaramuzzi RJ, Adams NR, Baird DT et al. (1993) A model for follicle selection and the determination of ovulation rate Reproduction, Fertility Development 5 459-478

Shackell GH, Hudson NL, Heath DA, Lun S, Shaw L, Condell L, Blay LR and McNatty KP (1993) Plasma gonadotrophin concentrations and ovarian characteristics in Inverdale ewes that are heterozygous for a major gene $\left(F e c X^{l}\right)$ on the $X$ chromosome that influences ovulation rate Biology of Reproduction 48 1150-1156

Sise JA, Montgomery GW and Hill DF (1991) DNA variation among seven New Zealand sheep breeds Proceedings of the New Zealand Society of Animal Production 51 47-53

Smith P, O WS, Corrigan KA, Smith T, Lundy T, Davis GH and McNatty KP (1997) Ovarian morphology and endocrine characteristics of female sheep fetuses that are heterozygous or homozygous for the Inverdale prolificacy gene $\left(\mathrm{FeC}^{1}\right)$ Biology of Reproduction 57 1183-1192

Souza CJ, Campbell BK, Webb R and Baird DT (1997) Secretion of inhibin A and follicular dynamics throughout the estrous cycle in the sheep with or without the Booroola gene (FecB) Endocrinology 138 5333-5340

Vaughan EK, Long SE, Parkinson TJ, Smith KC and Noakes DE (1997) Ovarian hypoplasia in Lleyn ewes Veterinary Record 140 100-101

Walling GA, Dodds KG, Galloway SM, Beattie AE, Lord EA, Lumsden JM, Montgomery GW and McEwan JC (2000) The consequences of carrying the Booroola fecundity $(\mathrm{FeCB})$ gene on liveweight. In Proceedings of the British Society of Animal Science, pp 43

Webb R, Driancourt M-A and Hanrahan JP (1998) Ovulation rate in the ewe: mechanisms underlying genetic variation. In The 6th World Congress on Genetics Applied to Livestock Production, University of New England, Armidale, Australia pp 3-10

Wheaton JE, Thomas DL, Kusina NT, Gottredson RG and Meyer RL (1996) Effects of passive immunization against inhibin-peptide on secretion of follicle-stimulating hormone and ovulation rate in ewes carrying the Booroola fecundity gene Biology of Reproduction 55 1351-1355

Wilkie PJ, Paszek AA, Beattie CW, Alexander LJ, Wheeler MB and Schook LB (1999) A genomic scan of porcine reproductive traits reveals possible quantitative trait loci (QTLs) for number of corpora lutea Mammalian Genome 10 573-578

Wilson T, Wu X-Y, Juengel JL et al. (2001) Highly prolific Booroola sheep have a mutation in the intracellular kinase domain of bone morphogenetic protein $1 \mathrm{~B}$ receptor which is expressed in both oocytes and granulosa cells Biology of Reproduction 64 1225-1235 